\title{
Jellyfish summer distribution, diversity and impact on fish farms in a Nordic fjord
}

\author{
Claudia Halsband ${ }^{1, *, * *}$, Sanna Majaneva ${ }^{1,2, * *}$, Aino Hosia ${ }^{3}$, Per Arne Emaus ${ }^{1}$, \\ Frank Gaardsted ${ }^{1}$, Qin Zhou ${ }^{1}$, Ole Anders Nøst ${ }^{1}$, Paul E. Renaud ${ }^{1,4}$ \\ ${ }^{1}$ Akvaplan-niva, Fram Centre, 9296 Tromsø, Norway \\ ${ }^{2}$ UiT, The Arctic University of Norway, 9037 Tromsø, Norway \\ ${ }^{3}$ University Museum of Bergen, 5020 Bergen, Norway \\ ${ }^{4}$ University Centre in Svalbard, 9171 Longyearbyen, Norway
}

\begin{abstract}
Jellyfish can cause high mortality of farmed fish and hence significant economic losses for the aquaculture industry. Despite their socio-economic importance, distribution and diversity data on gelatinous plankton are scarce from northern Norwegian fjords and other Nordic systems. Intense blooms of jellyfish have repeatedly been observed in Ryggefjord, Finnmark (Norway), sometimes concurrent with severe health problems of salmon. In the present study, the jellyfish community of this fjord was studied in summer 2015. In July, at least 13 species were identified using a combination of morphological and molecular techniques. High densities of small Beroe spp. and ctenophore larvae in cydippid stage dominated the surface waters. Adult Beroe cucumis were also present. Molecular identification revealed the presence of juvenile Euphysa tentaculata, as well as 2 species each of Clytia and Obelia. Obelia longissima was identified from both its pelagic (medusa) and benthic (polyp) stages, indicating that some local populations can complete their entire life cycle in the fjord. Abundances were significantly different between inner and outer parts of the fjord, and in relation to the prevailing wind direction. A dense bloom of the hydrozoan Dipleurosoma typicum in September coincided with high mortalities of farmed fish, suggesting a causal relationship. We conclude that the jellyfish assemblage in Ryggefjord is dynamic on short time scales and structured by both oceanographic conditions and local reproduction. A better understanding of seasonal population development and the relationships between hydrography, abundance and species composition is required to develop mitigation strategies for aquaculture operations.
\end{abstract}

KEY WORDS: Aquaculture $\cdot$ Arctic $\cdot$ Beroe spp. D Dipleurosoma typicum $\cdot$ Jellyfish bloom $\cdot$ Norway

\section{INTRODUCTION}

Jellyfish (here Cnidaria and Ctenophora) have received increasing attention in the last 2 decades, as their blooms sometimes occur in conflict with human maritime activities (Purcell 2012). The debate over whether jellyfish blooms have actually increased in magnitude and frequency (Richardson et al. 2009, Brotz et al. 2012) or simply that reporting has improved (Condon et al. 2013) is ongoing, but dramatic

${ }^{*}$ Corresponding author: claudia.halsband@akvaplan.niva.no

** These authors contributed equally to this work.

$\S$ Advance View was available online October 23, 2017 fluctuations in jellyfish biomass are known from high latitude systems (Eriksen et al. 2012). Knowledge gaps in basic jellyfish ecology, diversity and bloom dynamics along the northern Norwegian coast and in the Barents Sea, however, prevent effective monitoring and management of jellyfish in Nordic marine environments, where aquaculture is a major industry.

In Norway, aquaculture of salmon, cod, rainbow trout and several shellfish species reaches high levels in many fjords and considerable growth is predicted

(C) The authors 2018. Open Access under Creative Commons by Attribution Licence. Use, distribution and reproduction are unrestricted. Authors and original publication must be credited.

Publisher: Inter-Research · www.int-res.com 
towards the year 2050, particularly in northern regions (DKNVS/NTVA 2012). Open net-pen aquaculture is the most common production technique. It provides a semi-natural environment, where the fish are confined, but in direct contact with parasites, organic waste and disease agents present in the water. Negative interactions between gelatinous zooplankton blooms and net-based fish aquaculture have been reported from Scandinavia, the British Isles and France (e.g. Hellberg et al. 2003, Rodger et al. 2011). Along the coast of Norway, only a few reports focus on the role of jellyfish in farmed fish mortality, but some incidents have been documented. Species implicated include the hydrozoans Apolemia uvaria (Båmstedt et al. 1998, Fosså 1998, Fosså \& Asplin 2002) and Muggiaea atlantica (Fosså et al. 2003, Hellberg et al. 2003), the scyphozoan Aurelia aurita (Emelianov 2001, Hosteland 2016) and the ctenophores Bolinopsis infundibulum (Båmstedt et al. 1998) and Mnemiopsis leidyi (Oppegård 2008). For example, the colony-forming Apolemia uvaria caused high fish mortalities in several Norwegian counties in the late 1990s and early 2000s (Rodger et al. 2011), including Finnmark (S. S. L. Olsen pers. comm.). The problems induced by jellyfish include both direct and indirect health effects on the fish. The most obvious effect is stinging of the fish skin and gills by the cnidocytes of medusae, both from species/individuals small enough to pass through the mesh of the cages and from amputated pieces of large jellyfish (Baxter et al. 2011, Lucas et al. 2014, Mianzan et al. 2014). Wounds from jellyfish stings may subsequently be infected by bacterial pathogens, such as Tenacibaculum maritimum (MarcosLópez et al. 2016). Although the pathogenesis and natural origin of these bacteria are obscure, it is clear that some jellyfish carry them and may thus be vectors of fish disease (Delannoy et al. 2011). Problems also arise when the jellyfish themselves are not harmful, but their enormous densities clog the mesh of the pens and the gills of the fish, preventing oxygenation and water exchange between the cage and the surrounding water and leading to hypoxia and suffocation of the fish (Nilsen 2011, Rodger et al. 2011, Lucas et al. 2014). This has been reported for the ctenophore $B$. infundibulum (Båmstedt et al. 1998). Punctual hemorrhages on the gills have been observed in conjunction with blooms of $M$. leidyi (Oppegård 2008), and anecdotal observations from fish farmers indicate that blooms of Beroe spp. in Finnmark cause stress behavior in farmed salmon (A. L. J. Hosia pers. comm.). Known behavioral reactions in penned fish include respiratory and osmoregula- tory stress, loss of appetite, lethargy and/or increased jumping frequency, and lead to reduced biomass and/or increased mortality (Lucas et al. 2014), followed by economic impacts through the loss of harvest, reduced sales and profits from low quality fish and increasing mitigation costs (Tiller et al. 2015). Other problems not related to fish health are escapes of farm fish, after the weight of the jellyfish pull down the pen netting (Emelianov 2011), with subsequent risks for the wild fish populations (e.g. McGinnity et al. 2003), as well as clogged fishing nets (e.g. Kvile 2015).

Here, we present the first study of the jellyfish community in the arctic Norwegian Ryggefjord (Finnmark County), where salmon aquaculture facilities have operated since 1999. The investigations were motivated by unpublished reports of intense blooms of hydromedusae in recent years, sometimes concurrent with severe damage to farmed fish. We present data on the distribution and species composition of the jellyfish community in July 2015 in relation to the location of the fish pens, together with measurements of hydrography and oceanographic modeling outputs, and additional observations from an intense hydrozoan bloom in September.

\section{MATERIALS AND METHODS}

\section{Study area}

Our investigations were carried out in Ryggefjord, northern Norway $\left(70^{\circ} 52^{\prime}\right.$ to $70^{\circ} 57^{\prime} \mathrm{N}, 24^{\circ} 53^{\prime}$ to $25^{\circ} 05^{\prime} \mathrm{E}$ ), a fjord that stretches $10 \mathrm{~km}$ inland from north to south at the northern coast of Finnmark County. The fjord has no sill at its entrance, but a shallow area marks the transition from the continental shelf to Ryggefjord and adjacent fjords, in contrast to deeper basins connecting the open Barents Sea with the larger Porsanger- and Laksefjord in the east (Fig. 1a). The deepest part of the fjord (242 m) is located close to the mouth, allowing free water exchange between the fjord and the shelf area. In the inner region, the fjord divides into 2 arms: Vesterbotn pointing to the southwest, and Austerbotn to the southeast, with a shallow area between them (approximately $10 \mathrm{~m}$ deep; Fig. 1b). Two fish pens are located at the western side of the fjord (Skinnstakkvika), approximately $200 \mathrm{~m}$ above the seafloor, which consists of rock and silt.

The unstructured grid 3-dimensional model FVCOM (Finite Volume Community Ocean Model; Chen et al. 2003) was used to simulate the coastal circulation in 

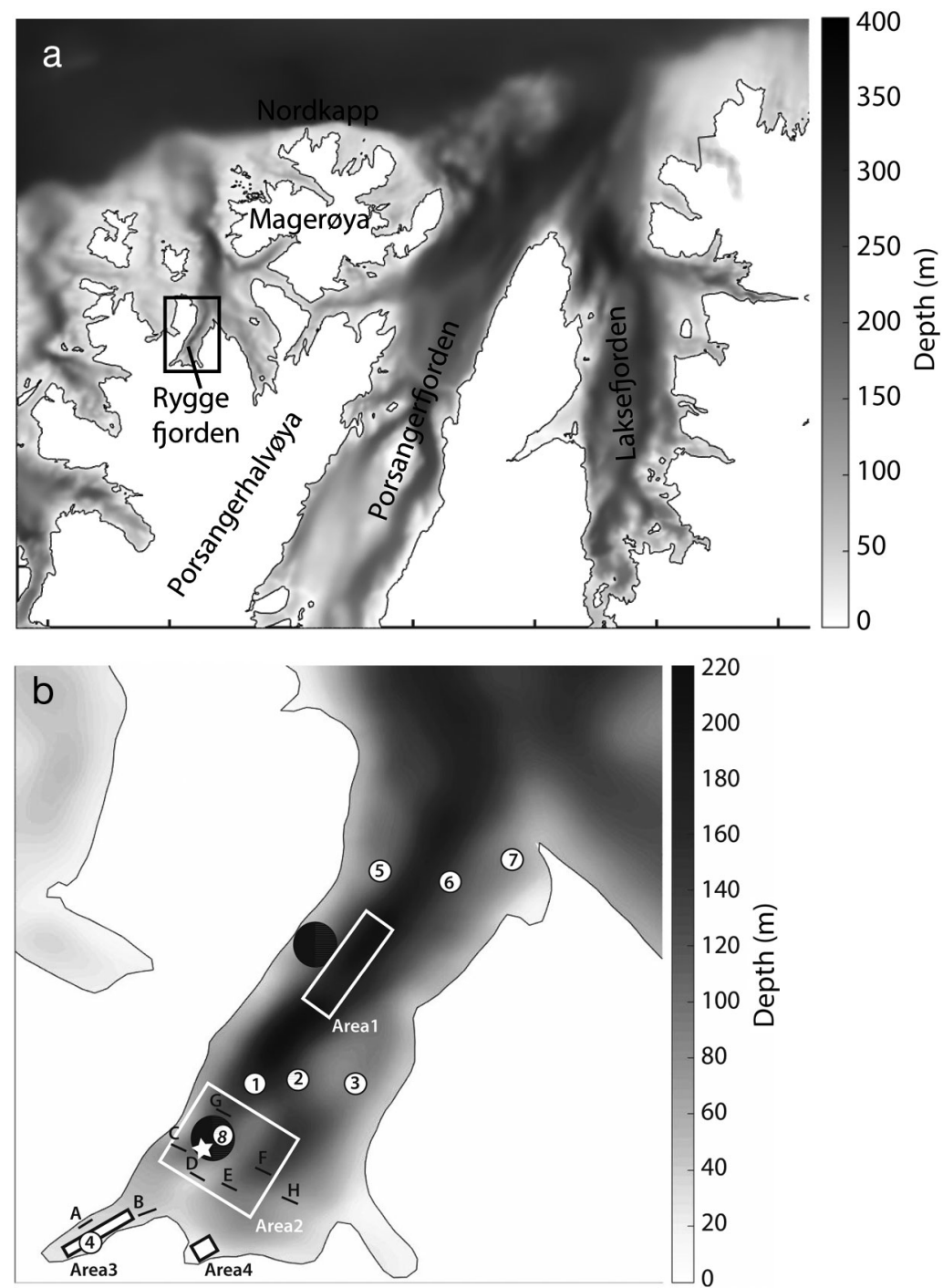

Fig. 1. (a) Ryggefjord in northern Norway (Finnmark) and (b) sampling locations: vertical nets $(1-8)$, horizontal nets $(A-H)$, visual observations (Areas 1-4) and polyp collection point (buoy; white star). The fish pens are marked as large black circles

the study area. The model domain covered the entire Finnmark County with a horizontal resolution ranging from $50 \mathrm{~m}$ in the fjords and near-coastal areas to about $800 \mathrm{~m}$ in the open ocean. The model had a total of 31 vertical layers with increasing resolution towards the surface. FVCOM was nested into the coastal model NorKyst-800 (Albretsen et al. 2011), which provided surface elevation, currents and water temperature/salinity at the open boundaries. Initial field values were also taken from NorKyst-800. River runoff data were based on model results from the Norwegian Water Resources and Energy Directorate (Beldring et al. 2003). A total of 3067 river discharge points were included in the FVCOM model setup. Atmospheric forcing fields with $2 \mathrm{~km}$ resolution were provided by the Integrated Community Limited Area Modeling System (ICLAMS; Solomos et al. 2011). The model ran for 21 mo from January 2013 through September 2014.

\section{Sampling}

Plankton sampling and jellyfish observations were carried out by boat between 28 and 31 July 2015. Plankton nets with $500 \mu \mathrm{m}$ mesh size equipped with a non-filtering cod-end were deployed to collect gelatinous zooplankton (WP-2 nets, KC Denmark AS, opening diameter $57 \mathrm{~cm}$ ). Eight stations were sampled (Fig. 1b), covering the whole fjord. Oblique tows were taken from different depths to the surface, depending on the bottom depth (Table 1). Temperature and salinity data were collected from the same depth strata with a Seabird SBE9/11+ CTD (Stns 2-8). In addition, 8 horizontal tows were taken at a standard speed of $0.7-0.8$ knots for $5 \mathrm{~min}$ at approximately $1.5 \mathrm{~m}$ depth, collecting approximately $25 \mathrm{~m}^{3}$ of waterper sampling in the vicinity $(<200 \mathrm{~m}$ ) of the inner fish pens (Fig. 1b; A-H). As larger specimens (>50 $\mathrm{mm}$ ) of jellyfish cannot be sampled effectively with plankton ring-nets, visual observations of the surface layer were conducted from a small boat (Fig. $1 \mathrm{~b}$; areas 1-4). Replicated abundance estimates were recorded within a standard area, where the surface waters were observed within $2 \mathrm{~m}$ to both sides of the boat and down to $\leq 2 \mathrm{~m}$ depth for 1 and $6 \mathrm{~min}$, at a speed of $0.7-0.8$ knots, which results in an observation volume of approximately 90 and $550 \mathrm{~m}^{3}$, respectively. Tissue material of hydrozoanid polyps was scraped off at a submersed buoy in the inner fish pen (white star in Fig. 1b) and preserved in ethanol for subsequent molecular identification. Due to their small size, individual numbers were indeterminable. In late September, an intensive hydrozoan bloom was observed, discoloring the surface waters. An additional surface sample was taken from the aquaculture platform with a bucket on the 21st of the month. Photos of the hydrozoans were taken to help identify the species causing the bloom. 
Table 1. Sampling locations (see Fig. 1) and wind conditions in Ryggefjord in summer 2015

\begin{tabular}{|c|c|c|c|c|c|c|c|}
\hline $\begin{array}{l}\text { Date } \\
\text { (dd.mm.yyyy) }\end{array}$ & Station & $\begin{array}{l}\text { Latitude } \\
\left({ }^{\circ} \mathrm{N}\right)\end{array}$ & $\begin{array}{l}\text { Longitude } \\
\left({ }^{\circ} \mathrm{E}\right)\end{array}$ & $\begin{array}{l}\text { Wind } \\
\text { direction }\end{array}$ & $\begin{array}{l}\text { Bottom } \\
\text { depth (m) }\end{array}$ & $\begin{array}{l}\text { Sampling } \\
\text { depth/time }\end{array}$ & Sample type \\
\hline \multirow[t]{4}{*}{28.07 .2015} & 1 & $70^{\circ} 53^{\prime} 52.6$ & $24^{\circ} 57^{\prime} 27.9$ & SSE & 156 & $50 \mathrm{~m}$ & Vertical tows \\
\hline & 2 & $70^{\circ} 53^{\prime} 52.6$ & $24^{\circ} 57^{\prime} 80.3$ & SSE & 156 & $50 \mathrm{~m}$ & Vertical tows \\
\hline & 3 & $70^{\circ} 53^{\prime} 05.6$ & $24^{\circ} 59^{\prime} 69.2$ & SSE & 99 & $50,90 \mathrm{~m}$ & Vertical tows \\
\hline & 4 & $70^{\circ} 52^{\prime} 63.2$ & $24^{\circ} 53^{\prime} 74.5$ & SSE & 36 & $30 \mathrm{~m}$ & Vertical tows \\
\hline \multirow[t]{6}{*}{29.07 .2015} & Area 1 & & & $\mathrm{~N}$ & & $1,6 \mathrm{~min}$ & Visual survey \\
\hline & 5 & $70^{\circ} 57^{\prime} 82.7$ & $25^{\circ} 02^{\prime} 24.3$ & $\mathrm{~N}$ & 80 & $50,90 \mathrm{~m}$ & Vertical tows \\
\hline & 6 & $70^{\circ} 55^{\prime} 74.4$ & $25^{\circ} 03^{\prime} 80.7$ & $\mathrm{~N}$ & 194 & $50,100 \mathrm{~m}$ & Vertical tows \\
\hline & 7 & $70^{\circ} 55^{\prime} 93.5$ & $25^{\circ} 05^{\prime} 54.6$ & $\mathrm{~N}$ & 88 & $50 \mathrm{~m}$ & Vertical tows \\
\hline & Area 2 & & & $\mathrm{~N}$ & & $1,6 \mathrm{~min}$ & Visual survey \\
\hline & A, B & & & $\mathrm{N}$ & & $5 \mathrm{~min}$ & Horizontal tow \\
\hline 30.07 .2015 & $\mathrm{C}-\mathrm{H}$ & & & NNE & & $5 \mathrm{~min}$ & Horizontal tow \\
\hline \multirow[t]{4}{*}{31.07 .2015} & Area 3 & & & $\mathrm{~N}$ & & 1, $6 \mathrm{~min}$ & Visual survey \\
\hline & Area 4 & & & $\mathrm{~N}$ & & $1,6 \mathrm{~min}$ & Visual survey \\
\hline & 8 & $70^{\circ} 53^{\prime} 009$ & $24^{\circ} 56^{\prime} 546$ & $\mathrm{~N}$ & 100 & $20,80 \mathrm{~m}$ & Vertical tows \\
\hline & Buoy (㳄) & & & $\mathrm{N}$ & & Surface & Scrapings \\
\hline 21.09 .2015 & Area 2 & & & $\mathrm{E}$ & & $1 \mathrm{~m}$ & Bucket \\
\hline
\end{tabular}

\section{Species identification}

Both morphological identification and DNA sequencing of selected individuals were applied. Collected specimens were gently sorted, identified and counted immediately after sampling. Individuals of each taxon were photographed alive in a glass aquarium and examined under a stereomicroscope (Leica, 16-40× magnification). Individuals were identified, mostly to genus level (e.g. Kramp 1959, Mills \& Haddock 2007), and counted. Photographed specimens were fixed in $99 \%$ ethanol and later transferred to $70 \%$ ethanol for molecular identification, except for the hydrozoans collected in September, which were identified from photos only (see Fig. 5b-d).

DNA was extracted from tissue of 30 morphologically distinct specimens (3-5 per habitus) and 2 samples of polyp tissues scraped off a buoy with a modified Chelex rapid-boiling procedure as described in Majaneva (2014). The amplifications were performed on a SimpliAmp ${ }^{\mathrm{TM}}$ Thermal Cycler with universal eukaryotic primers for the internal transcribed spacer 1 (ITS1) for ctenophores (Majaneva 2014) and for the 16S rRNA gene for hydrozoans (Schuchert 2005). PCR products were purified using the illustra GFX PCR DNA and Gel Band Purification Kit (GE Healthcare) according to the manufacturer's instructions. Cycle sequencing of the PCR products (both directions) was carried out by Macrogen Sequencing Service (South Korea). The resulting nucleotide sequence electropherograms were checked for poor base calls by eye and sequence quality using Chromas Lite 2.1 (Technelysium). Good-quality sequences were assembled using BioEdit software (Hall 1999) and blasted in BLASTN 2.6.0 (Altschul et al. 1997) for comparison with existing sequences in the NCBI GenBank database (https://blast.ncbi.nlm. nih.gov/). The sequences reported here have been deposited in the European Nucleotide Archive (ENA) (see Table 3).

\section{Data analysis}

Densities and species composition of the jellyfish community sampled in the vertical net tows were compared in Primer 7. The data were square root transformed and analyzed with a PRIMER CAP (canonical analysis of principal coordinates) that consists of a principal coordinate analysis (PCO), followed by generalized discriminant analysis (GDA) based on Bray-Curtis dissimilarity (Anderson \& Robinson 2003, Anderson \& Willis 2003). We tested whether the sampling stations (1-8) showed significant grouping using 4 location parameters within the fjord (inner, middle, outer fjord and fish pen, Fig. 1b) with bottom depth, sampling depth and wind direction (Table 1) as variables. The program determined the appropriate number of dimensions $(\mathrm{m})$ used in the PCO and CAP with a maximum of 9999 permutations. 


\section{RESULTS}

The hydrographic conditions were homogeneous throughout the fjord, with a slightly warmer and fresher surface layer down to about $10 \mathrm{~m}$ depth with temperatures between 8 and $9^{\circ} \mathrm{C}$ and deep waters $>100 \mathrm{~m}$ at around $6.8^{\circ} \mathrm{C}$ (Fig. 2). Station 8 within the fish pen was warmest in the upper $10 \mathrm{~m}$ with a maximum temperature of $10.1^{\circ} \mathrm{C}$ recorded at the surface on 31 July at midday. Salinities ranged from 33.0 at the surface to 34.7 at $130 \mathrm{~m}$ depth. Results from FVCOM modeling for the year 2013 show that current directions within the fjord are variable in July, and that advection events usually bring in waters on the western side of the fjord (Fig. 3a,b), while the outflow occurs mainly on the eastern side (not shown). Surface temperatures in the fjord increased from $<9^{\circ} \mathrm{C}$ in July to $>10^{\circ} \mathrm{C}$ in September (Fig. 3c,d).

A total of 5766 specimens from 18 taxonomic categories were recorded and identified to species, genus, or in some cases, family level (Table 2$)$. Small $(<5 \mathrm{~mm}$ ) Beroe spp., present at all sampling locations, were the most abundant and reached densities of up to 4.25 and 65.6 ind. $\mathrm{m}^{-3}$ in vertical and horizontal net tows, respectively, followed by ctenophore larvae in the cydippid stage and Euphysa spp. (Fig. 4a,b). Beroe spp.

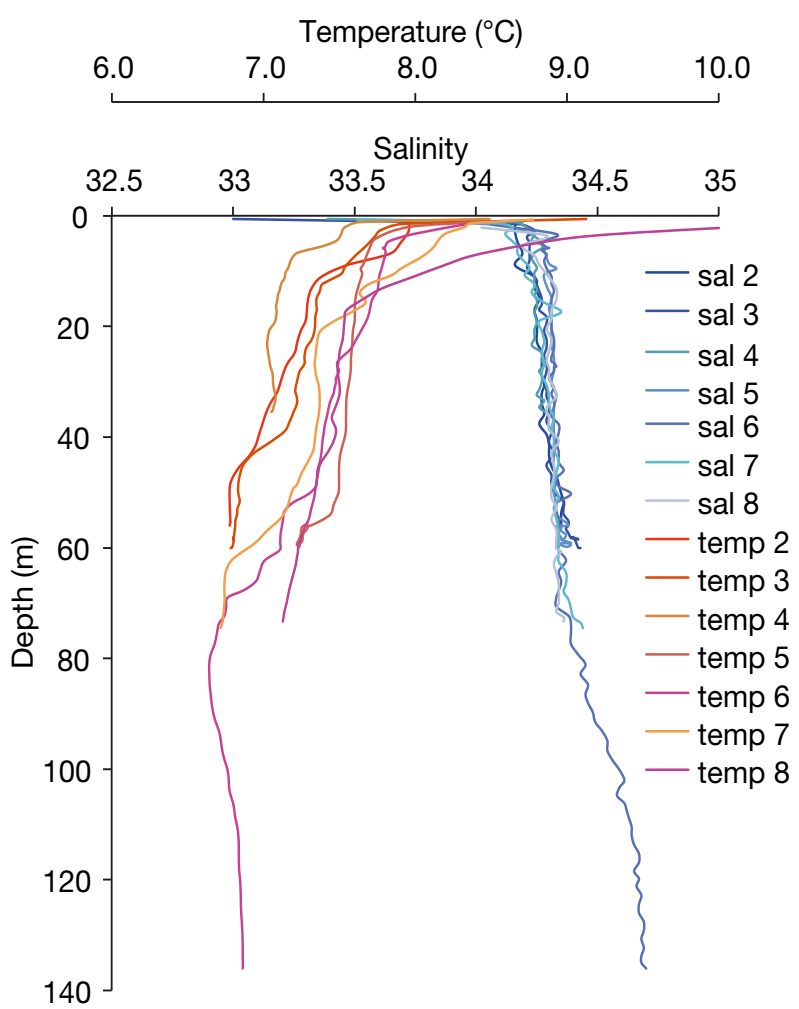

Fig. 2. Temperature $\left({ }^{\circ} \mathrm{C}\right)$ and salinity depth profiles at Stns 2-8 in July 2015 constituted $86 \%$ of all individuals in vertical net tows, while Euphysa spp. and Obelia spp. constituted 3\% and $1 \%$, respectively. Unidentified cydippid larvae, which may include larvae of lobate and/or cydippid ctenophores, made up to $6 \%$ of the community. Larger individuals $(>50 \mathrm{~mm}$ ) included the scyphomedusae Aurelia aurita and Cyanea capillata, the hydrozoan Staurostoma mertensii and large specimens of the ctenophores Beroe cucumis and Bolinopsis infundibulum, which could be identified to species. These were observed both during visual surveys (Fig. 4c) and as tissue pieces present in the net samples. Other medusae, such as Aglantha digitale, Clytia spp., cf. Plotocnide borealis and Rathkea octopunctata, were present, but in smaller numbers (Table 2). We also observed a few individuals of an unidentified cydippid with a habitus similar to that of Haeckelia beehleri, but could not confirm this molecularly. The hydrozoan Dipleurosoma typicum was not recorded in July, but formed a dense bloom in the inner fjord 2 mo later (Fig. 5a-d), accompanied by high fish mortalities in the local pens (S. S. L. Olsen pers. comm., S. B. Småge et al. pers. comm). Large numbers of benthic stages of different cnidarians, including scyphistomatid and campanularid hydroids, were observed on the submerged structures of the fish farm (Fig. 5e).

Additional DNA analyses allowed a more detailed assessment of the pelagic species composition. A BLASTN search of the obtained nucleotide sequences in the NCBI GenBank database (26 December 2016) revealed the following species identifications. For the hydrozoans, nucleotide sequences showed $100 \%$ match with the 16S rRNA gene sequence of Euphysa tentaculata (EU876537 with 0-1 bp difference) for 2 individuals that had been morphologically identified as Euphysa cf. aurata (Tables 2 \& 3). Four individuals of Obelia spp. all showed 99\% match with Obelia geniculata (KX665358.1 with 2-3 bp difference), while of 3 morphologically identified Clytia specimens, one corresponded to Clytia gracilis (KX665334.1 with 9 bp difference) and 2 to Clytia hemisphaerica (KX665291.1 with 3 bp difference). Eight Beroe individuals had a 99\% match with Ctenophora sp. H1 (HF912431.1 with 1-2 bp difference, $74 \%$ query coverage; Majaneva \& Majaneva 2013) and $93 \%$ match with Beroe cucumis (AF293695.1, 49 bp difference with 14 gaps, $96 \%$ query coverage). Three unidentified cydippid larvae with no close matches $(\leq 92 \%)$ were also recorded (Table 3). An indeterminable number of hydrozoanid polyps collected from the buoy (star in Fig. 1b) showed a $100 \%$ match with O. longissima (KX665302.1) and a $99 \%$ match with O. geniculata 

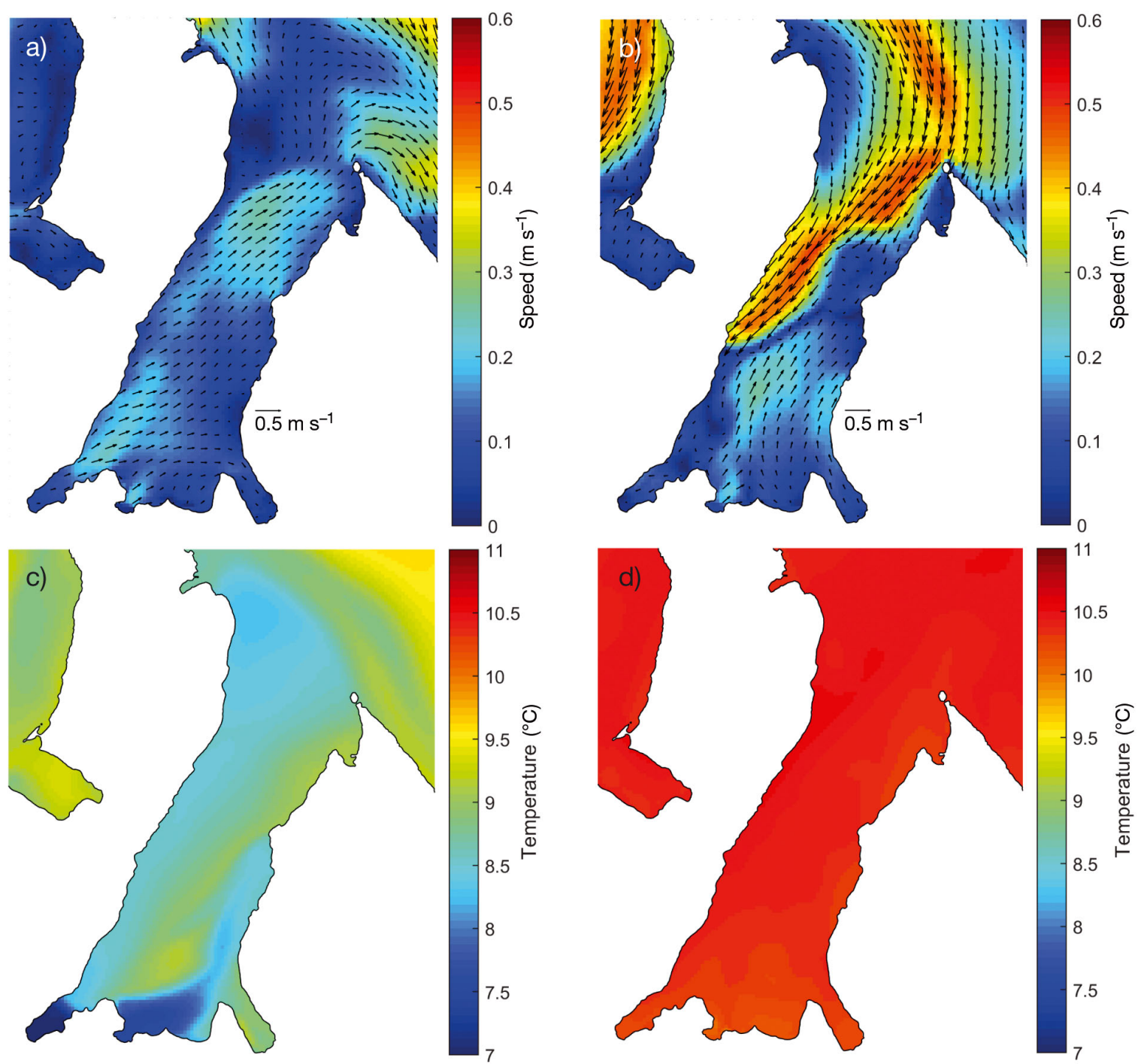

Fig. 3. Oceanography of Ryggefjord at $5 \mathrm{~m}$ depth from FVCOM model outputs for summer 2013. (a) Outward current pattern and (b) advection event with inflow from the northwest (arrows denote current strength and direction, the color scale indicates current speed). (c,d) Horizontal temperature distribution in (c) July and (d) September

(KX665358.1). The sequences obtained from O. geniculata medusae and polyps were identical (MF662617).

Beroe spp. were common at all stations, but abundances showed a bimodal distribution with high abundances in both the inner and outer fjord, whereas fewer individuals were recorded at stations 2 and 3 (Fig. 4a). Small Beroe spp. were also abundant at Stn G (northeast of the inner fish pen) and larger individuals, similarly to Aurelia aurita, were abundant in visual surveys in area 2 near the inner fish pen (Fig. 4b,c). Euphysa spp. showed the opposite pattern, with the highest numbers in the middle of the fjord (Fig. 4a). Bolinopsis infundibulum, together with Aglantha digitale and Obelia spp., were more common in the outer parts of the fjord, while the cydippid larvae populated the middle parts. The PCO and CAP largely confirmed the patterns observed and showed the clustering of replicate vertical net tows grouped by sampling location, with 4 taxa causing the differences: Bolinopsis infundibulum, Clytia spp., Euphysa spp. and cydippid larvae (Fig. 6). There were significant differences between 4 groups of sampling locations (stations located in the outer, middle and inner fjord and within the fish pen) and between 2 groups of stations sampled during differing prevailing wind conditions. Neither bottom nor sampling depths had significant effects on jellyfish abundance, and the CAP analyses had very high misclassification errors due to low numbers of samples in each group (Table 4). 
Table 2. Pelagic stages of gelatinous zooplankton found in Ryggefjord in summer 2015 (morphological identification). Note that Euphysa cf. aurata was subsequently identified as E. tentaculata through sequencing of the 16S rRNA gene (see Table 3), and may thus have been misidentified here. Dipleurosoma typicum was identified from photographs taken of surface samples under a microscope

\begin{tabular}{|llll|}
\hline Taxon & Phylum & Class/order & Sample type \\
\hline Beroe cucumis & Ctenophora & Beroida & Plankton net \\
Beroe spp. & Ctenophora & Beroida & Plankton net \\
Bolinopsis infundibulum & Ctenophora & Lobata & Plankton net \\
Ctenophore, lobate larvae & Ctenophora & Lobata & Plankton net \\
Ctenophore, indet. & Ctenophora & Tentaculata/Cydippida & Plankton net \\
Ctenophore, cydippid larvae & Ctenophora & Tentaculata/Cydippida & Plankton net \\
Aglantha digitale & Cnidaria & Hydrozoa/Trachymedusae & Plankton net \\
Clytia spp. & Cnidaria & Hydrozoa/Leptothecata & Plankton net \\
Dipleurosoma typicum & Cnidaria & Hydrozoa/Leptothecata & Photo \\
Euphysa cf. aurata & Cnidaria & Hydrozoa/Anthoathecata & Plankton net \\
Obelia spp. & Cnidaria & Hydrozoa/Leptothecata & Plankton net \\
cf. Plotocnide borealis & Cnidaria & Hydrozoa/Anthoathecata & Plankton net \\
Rathkea octopunctata & Cnidaria & Hydrozoa/Anthoathecata & Plankton net \\
Staurostoma mertensii & Cnidaria & Hydrozoa/Leptothecata & Visual observation \\
Hydrozoa indet 1 & Cnidaria & Hydrozoa & Plankton net \\
Hydrozoa indet 2 & Cnidaria & Hydrozoa & Plankton net \\
Aurelia aurita & Cnidaria & Scyphozoa/Semaeostomeae & Visual observation \\
Cyanea capillata & Cnidaria & Scyphozoa/Semaeostomeae & Visual observation \\
\hline
\end{tabular}

\section{DISCUSSION}

The jellyfish community in July 2015 included both ctenophores and several cnidarian species, but exhibited a clear numerical dominance of small $(<5 \mathrm{~mm})$ Beroe spp. Blooms of Beroe spp. are common in northern Norwegian fjords: large volumes of Beroe spp. have been recorded in Malangen (Troms County), where the ctenophore population was followed throughout the seasonal cycle (Falkenhaug 1996). Both small Beroe spp. (vertical net samples) and large ones (visual observations) were abundant inside and around the fish pens, but did not seem to interfere with the fish. Beroe cucumis was one of the Beroe species observed, but at least one more species was present based on the molecular results, as the larvae did not match $B$. cucumis sequences. Cydippid-like larvae were also common and were most abundant inside the fjord in the horizontal tows (Fig. $4 \mathrm{~b})$, potentially reflecting a local reproduction event of another ctenophore. Since the Beroidae are the only ctenophore family without cydippid-like larvae, other species must have produced these. Bolinopsis infundibulum is a potential candidate, but the adult specimens at the mouth of the fjord were not colocated with the larvae in the inner fjord during the time of sampling. Some of the unidentified cydippids had a habitus resembling that of Haeckelia beehleri, but it is unlikely that this species was present in Ryggefjord, since it is a subtropical species in the central Atlantic and east Pacific (Haddock \& Case 1995), and has not been observed this far north.

Although the hydrography was homogeneous throughout the fjord, the jellyfish distribution was not uniform. Different taxa had peak abundances at different locations within the fjord: small Beroe spp. had a wide distribution pattern at both inner and outer stations, but lower abundance in the middle of the fjord (Stns 2 and 3), while Euphysa spp. exceeded Beroe spp. abundances at these stations. The cydippid-like larvae were most abundant at Stns A, B, and 1, 2 and 5 and thus less numerous at the outermost stations. Large individuals of Aurelia aurita and Bolinopsis infundibulum were mainly recorded at the stations near the inner fish pen. Although our sampling was conducted on calm summer days, the prevailing wind conditions seemed to play a role in structuring jellyfish distribution, as stations sampled during southwesterly winds (1-4) differed significantly from stations sampled during northerly winds (5-8). The observed change in wind direction, however, coincided with a change of sampling location and thus the effect of wind direction may simply reflect that of location (Tables $1 \& 4$, Fig. 6). Aggregations of jellyfish due to certain wind conditions have been reported elsewhere, e.g. in Kaldfjord (Troms County), where a mass occurrence of Aurelia aurita caused salmon to escape from their enclosures (Nilsen 2011). This indicates that wind patterns 


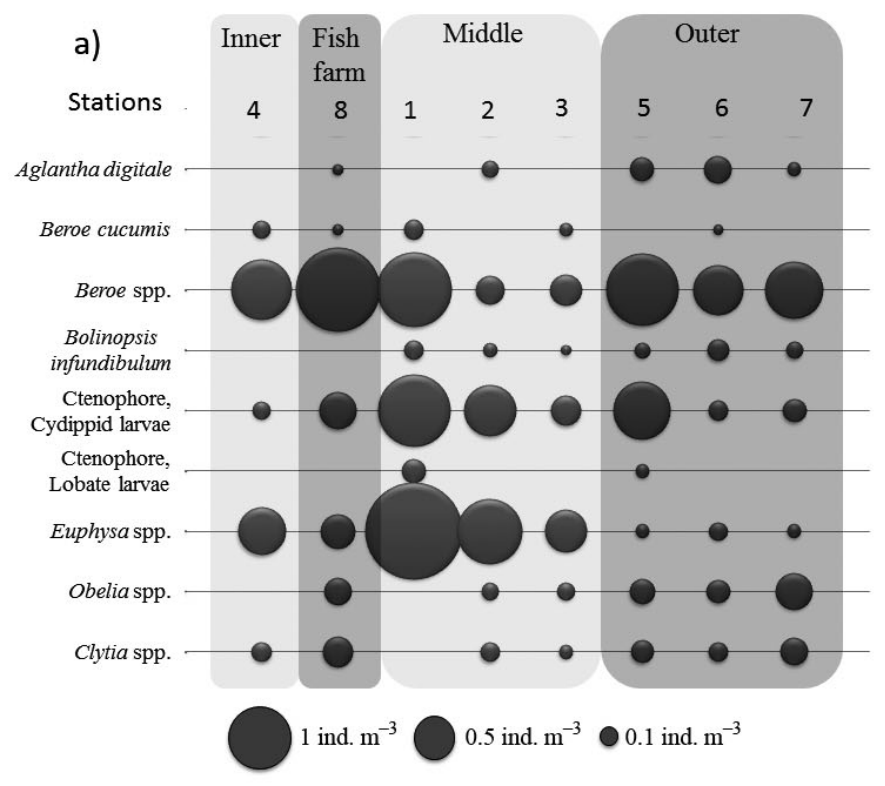

b)

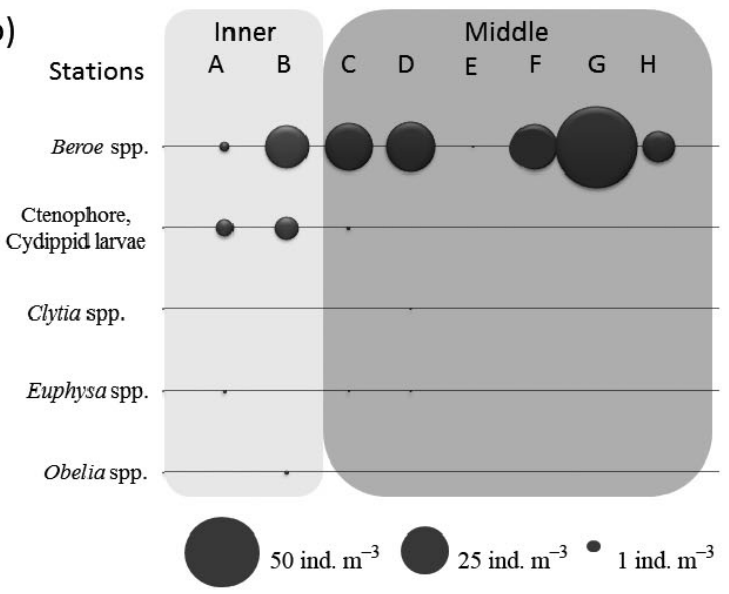

c)

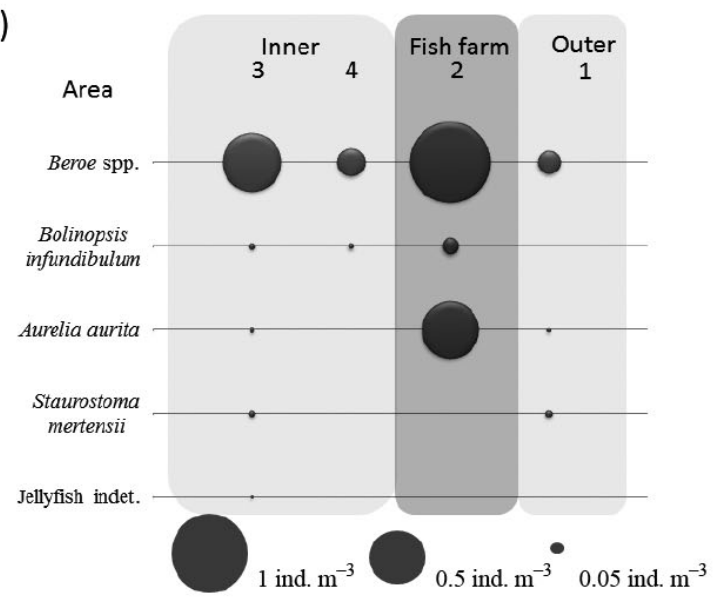

Fig. 4. Abundance of the most common jellyfish taxa in the inner, middle and outer parts of Ryggefjord and at the fish farm in July 2015. (a) Vertical net tows, (b) horizontal net tows at the surface, and (c) visual surveys may play an important role in creating jellyfish hot spots.

Although we were unable to follow the jellyfish community over an extended period of time, it is clear that changes in species composition and dominance occur on relatively short time scales (weeks): the hydrozoan Dipleurosoma typicum formed a dense bloom in late September, while it was not recorded at all in the assemblage $8 \mathrm{wk}$ earlier (Table 2). The FVCOM model outputs (Fig. 3c,d) show typical temperature differences between July and September. These may play a significant role in the population dynamics of this species. For example, a minimum of $10^{\circ} \mathrm{C}$ is required for successful proliferation of the siphonophore Muggiaea atlantica in the English Channel (Blackett et al. 2015), and Dipleurosoma bloom formation may be driven by a similar temperature threshold. A bloom of Rathkea octopunctata occurred in nearby Porsangerfjord (see Fig. 1a) in August 2014 (Varela 2015), while it was very rare in our samples, demonstrating the high spatial and temporal variability in jellyfish communities.

The molecular species identification generated 21 sequences for 7 taxa (Table 3 ). The species list presented here is nonetheless incomplete. Species identification of gelatinous zooplankton, and of juvenile individuals in particular, is challenging due to either a lack of developed features or morphological similarity between closely related species. For example, the difficulty of assigning the characteristic cydippidlike larvae is due to the few diagnostic features that distinguish species (Majaneva 2014). For the hydromedusae, juvenile specimens morphologically identified as Euphysa aurata had a 100\% molecular match with Euphysa tentaculata (with 0-1 bp difference) and were thus misidentified, but this falsepositive error does not preclude that E. aurata was also present. More supporting molecular evidence is needed to correctly relate larvae to adults, and thus identify larvae to the species level. Specimens of the genus Clytia included 2 species: C. gracilis and C. hemisphaerica (Table 3). The taxonomy of these Clytia species is currently unresolved, and both are likely part of a complex of cryptic species. A molecular identification of $D$. typicum is currently not feasible, since there are no existing published sequences available for comparison. Hydrozoanid polyps collected from the buoy showed a $100 \%$ match with Obelia longissima and a $99 \%$ match with O. geniculata, while only $O$. geniculata medusae were found in the water column. This may indicate that the 2 congeners have different phenology and produce medusae at different times, or according to differing 

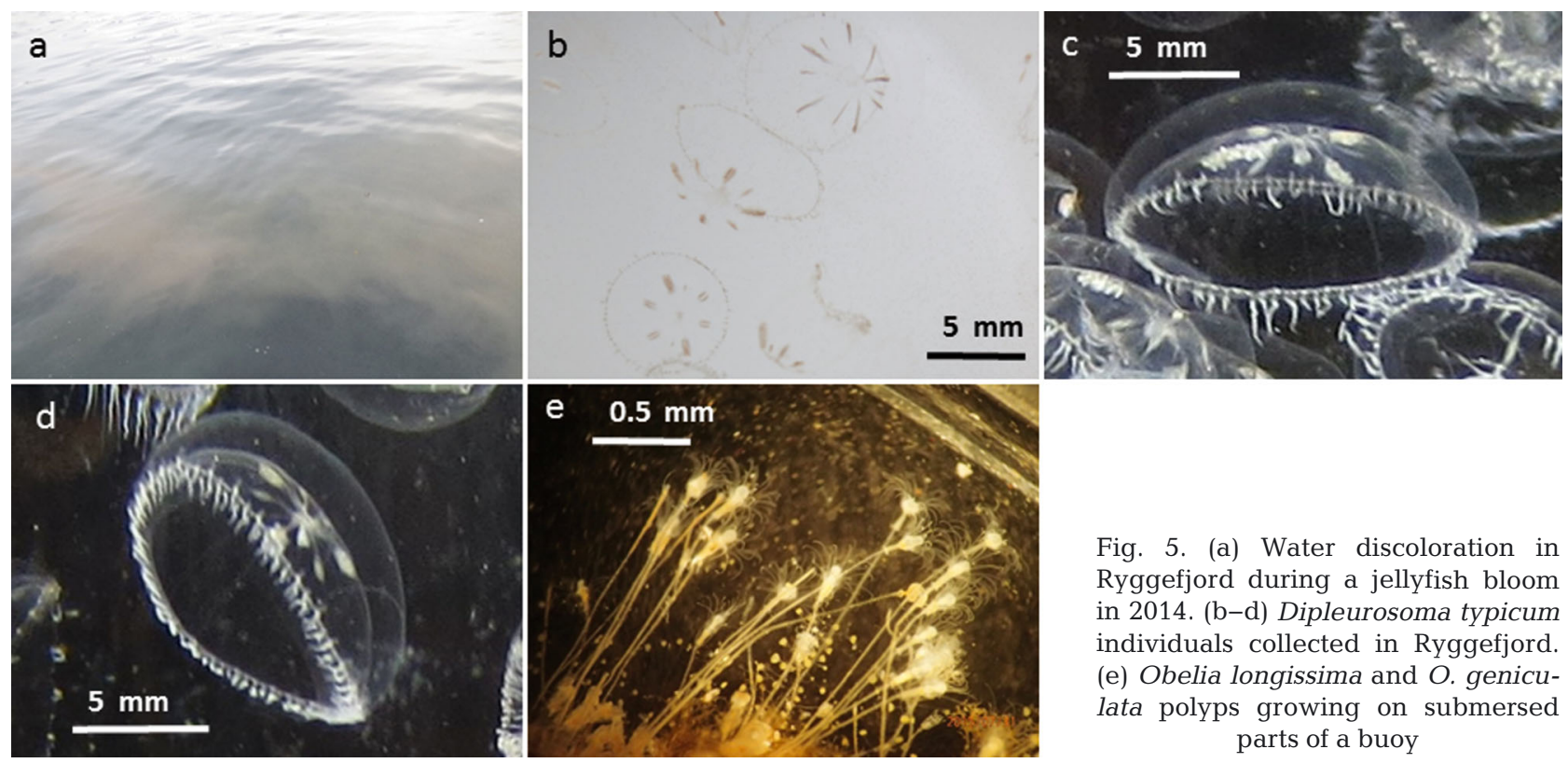

Fig. 5. (a) Water discoloration in Ryggefjord during a jellyfish bloom in 2014. (b-d) Dipleurosoma typicum individuals collected in Ryggefjord. (e) Obelia longissima and O. geniculata polyps growing on submersed parts of a buoy

Table 3. Jellyfish individuals identified both morphologically and molecularly (16S rRNA gene for hydrozoans; nuclear ITS1 gene for ctenophores)

\begin{tabular}{|lccclcr|}
\hline Morphological ID & $\begin{array}{c}\text { Life } \\
\text { phase }\end{array}$ & $\begin{array}{c}\text { No. of } \\
\text { individuals }\end{array}$ & Gene & Molecular ID & $\begin{array}{c}\text { BLASTN } \\
\text { match }(\%)\end{array}$ & $\begin{array}{c}\text { Accession } \\
\text { number }\end{array}$ \\
\hline Clytia spp. & Pelagic & 1 & $16 \mathrm{~S}$ & Clytia gracilis & 99 & MF662615 \\
& & 2 & $16 \mathrm{~S}$ & Clytia hemisphaerica & 99 & MF662616 \\
Euphysa cf. aurata & Pelagic & 2 & $16 \mathrm{~S}$ & Euphysa tentaculata & 100 & MF662614 \\
Obelia sp. & Pelagic & 4 & $16 \mathrm{~S}$ & Obelia geniculata & 99 & MF662617 \\
Staurostoma mertensii & Pelagic & 2 & $16 \mathrm{~S}$ & Staurostoma mertensii & 99 & MF662613 \\
Cnidaria (polyps) & Benthic & $?$ & $16 \mathrm{~S}$ & Obelia geniculata & 99 & MF662617 \\
& Benthic & $?$ & $16 \mathrm{~S}$ & Obelia longissima & 100 & MF662618 \\
\hline Beroe spp. & Pelagic & 8 & ITS1 & Ctenophora sp. H1 & 99 & MF662620 \\
Ctenophore, cydippid larvae & Pelagic & 3 & ITS1 & Ctenophora & $\leq 92$ & MF662619 \\
\hline
\end{tabular}

temperature preferences. Alternatively, low abundances may prevent their occurrence in net samples. These examples show that the combination of morphological and molecular identification is necessary for data interpretation in ecological studies (McManus \& Katz 2009, Majaneva 2014).

High fish mortality was observed in the Ryggefjord fish farm during the winter of 2002 and in late summer 2012, 2014 and 2015 (S. S. L. Olsen pers. comm.). In 2014, the salmon were lethargic, refused food and showed lesions on their gill covers, gill tissues and throats. Feed refusals may indicate that the fish tried to avoid the stings, and gill clogging was possibly also a problem. In 2015, in contrast, the clinical symptoms pointed to a tenacibaculosis (S. B. Småge et al. pers. comm.). A severe mortality inci- dent in 2002 in nearby Vinnalandet (Finnmark) was attributed to an outbreak of Apolemia uvaria (S. S. L. Olsen pers. comm.), which affected almost the entire coastline of Norway (Båmstedt et al. 1998, Rodger et al. 2011) (Table 5). This colonial siphonophore was

Table 4. Canonical analysis of principal coordinates (CAP) of vertical net samples. m: no. of dimensions; n: no. of samples

\begin{tabular}{|cclcc|}
\hline $\mathrm{m}$ & $\mathrm{n}$ & $\begin{array}{l}\text { Grouping } \\
\text { variable }\end{array}$ & $\mathrm{p}$-value & $\begin{array}{c}\text { Misclassification } \\
\text { error (\%) }\end{array}$ \\
\hline 4 & 21 & Location & 0.001 & 33.3 \\
3 & 21 & Wind direction & 0.001 & 14.3 \\
4 & 21 & Sampling depth & 0.538 & 57.1 \\
3 & 21 & Bottom depth & 0.088 & 47.6 \\
\hline
\end{tabular}



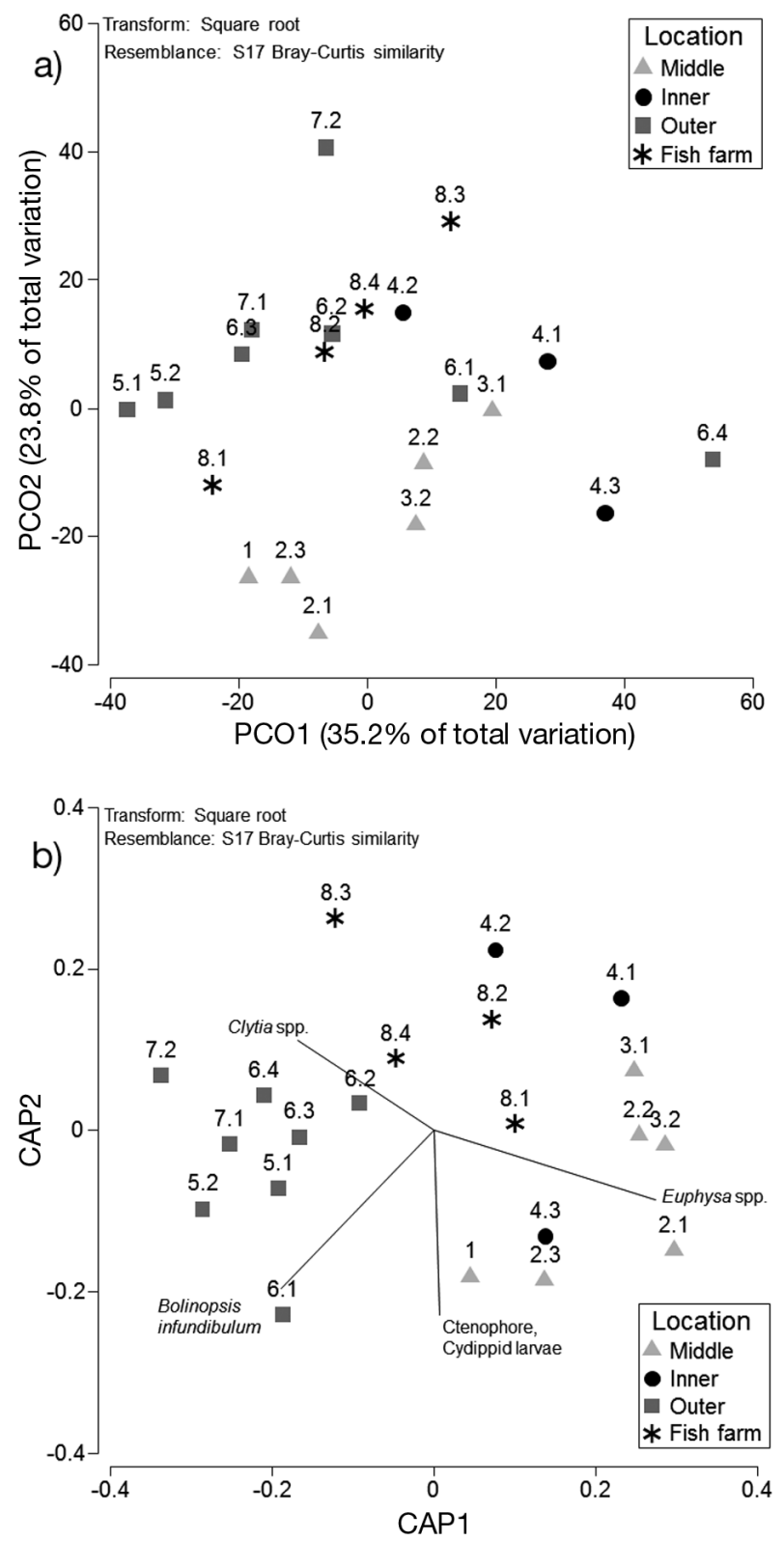

Fig. 6. (a) Principal coordinate analysis (PCO) followed by (b) canonical analysis of principal coordinates (CAP), with Bray-Curtis dissimilarity as a distance measure. The 4 species contributing most to the differences between location groups (correlations with the canonical axes $>0.5$ ) are also shown. To increase visibility of individual stations, the correlation lines have been shortened $(\mathrm{X}, \mathrm{Y}$ coordinates: $B o-$ linopsis infundibulum $-0.57,-0.59$; cydippid larvae 0.02 , -0.69 ; Euphysa spp. 0.74, -0.35 ; Clytia spp. $-0.50,0.33$ )

not present in our samples. The fish kills in the later years, in contrast, were associated with non-colonial hydrozoan blooms. We identified the culprit behind the harmful blooms in September 2012, 2014 and 2015 as Dipleurosoma typicum (Boeck, 1868) based on its morphological features including size, shape,

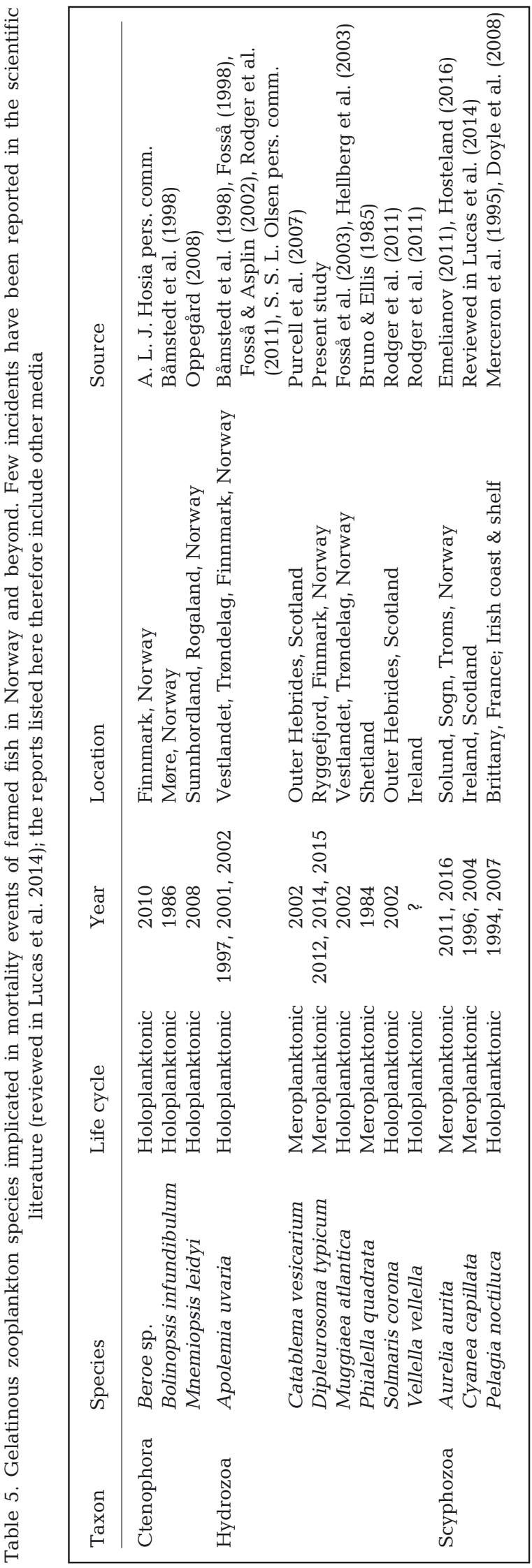


number of tentacles, and in particular the varying number of irregularly arranged radial canals and associated gonads (Fig. 5b-d). The medusae were initially misidentified as Halopsis ocellata in 2012, a different species in the order Leptothecata, but a reassessment from photographs clearly identifies them as D. typicum. To our knowledge, this is the first time $D$. typicum has been reported to be associated with severe problems for fish farming. The type locality of $D$. typicum is in southwest Norway (Boeck 1866), but we could find no evidence of further observations from Norwegian waters since the original description. It has been suggested to have a borealcircumpolar distribution (Cornelius 1995). In the Atlantic, D. typicum has been commonly recorded along the coast of the British Isles and Ireland, but has also been reported from Newfoundland. Recurring blooms have been reported from Valentia Island, SW Ireland, in the past, where dense swarms have caused discolorations of the water (Russell 1953) (Fig. 5a). D. typicum has a bi-phasic life cycle (Cornelius 1995) with a benthic polyp stage in addition to the pelagic medusa observed in this study. The polyp stage of $D$. typicum has not been definitively identified, but earlier rearing experiments suggest it belongs to Cuspidella, a nominal genus combining several minute, stolonal, morphologically similar hydroids with an unidentified medusa stage (Russell 1953, Cornelius 1995).

The sources of the reported Apolemia and Dipleurosoma blooms in Ryggefjord may have been different: while Dipleurosoma may be of local origin, blooms of Muggiaea atlantica and Apolemia uvaria were advected to Norwegian coasts from further south (Båmstedt et al. 1998, Fosså \& Asplin 2002). The presence of different life stages (polyps and medusae of cnidarians; larvae and adults of Beroe spp.; adult Bolinopsis sp. and cydippid larvae) suggests the presence of local populations that complete their entire life cycle within Ryggefjord. For example, Obelia longissima was recorded with both its pelagic (medusa) and benthic (polyp) stages in late July. In addition, many unidentified scyphistomatid and campanularid hydroids were observed on submersed structures of the fish farm in Ryggefjord during our study (Fig. 5e). Many of these probably belong to the Clytia and Obelia species recorded in the water column, but Dipleurosoma/Cupsidella polyps may also be present. Their habitat has not yet been located, but their distribution - together with favorable environmental conditions - may play a crucial role in the formation of medusae blooms (Boero et al. 2008). Increased availability of artificial substrates may boost populations of species with a benthic life stage such as D. typicum (Duarte et al. 2013). A $\sim 4$-fold increase in the number of Aurelia aurita ephyrae was observed in a fishing port in Japan after a pier was built close by (Makabe et al. 2014). Aquaculture constructions themselves may in fact contribute to increased jellyfish numbers by providing substrate for their benthic stages, as well as restricting local water exchange (Lo et al. 2008). An increased benthic sampling area and larger sample sizes would facilitate a more comprehensive mapping of resident populations with complete bentho-pelagic life cycles. Efforts to search for the origin of the medusae should be undertaken to be able to forecast their seasonal abundance and thus to provide specific recommendations for mitigation strategies to the aquaculture industry.

In contrast, oceanographic modeling shows that strong advective inflow may represent an important transport pathway for blooms and may create differential stage distributions, depending on species- and stage-specific depth preferences. The FVCOM modeling showed that advection events usually bring in sub-surface waters on the western side of Ryggefjord, while the outflow occurs mainly at depth on the eastern side. The fish pens are located along the western shoreline, and are thus located in a main inflow area. This may increase their exposure to blooms that are advected into Ryggefjord with the currents. Combining jellyfish abundances, oceanographic model outputs forced with data from the same year, and particle tracking analyses may give valuable insights into small- and meso-scale jellyfish bloom movements on the Finnmark shelf and in the fjords. Early warning may be provided for these kinds of harmful blooms if they are observed upstream of areas with aquaculture operations with the help of fine-scale ocean current modeling (Fosså \& Asplin 2002).

The undesirable impacts of jellyfish on aquaculture have received less attention than impacts on netbased fisheries, although reports exist from various locations around the world with several taxa reported to have caused problems, including blooms resulting in large losses of farmed fish (Table 5). Such events are often only mentioned in the popular media, with few reports in the scientific literature (e.g. Fosså 1998, Fosså \& Asplin 2002, Rodger et al. 2011). Less severe incidents usually remain undocumented by authorities or scientists. Consequently, there is limited information on which species cause problems. The surprising find of a harmful $D$. typicum bloom at a northern Norwegian location demonstrates the lack 
of knowledge on the distribution of gelatinous zooplankton in Norwegian waters, particularly in the northern areas. Both fish kills and sublethal effects of jellyfish interactions with farmed fish can contribute to economic losses, e.g. through reduced growth due to stress or increased exposure to disease where jellyfish act as vectors (Delannoy et al. 2011). Thus, understanding the extent of the problem as well as identifying key taxa responsible remains a challenge, if mitigation strategies are to be developed. New technologies may lead to the development of cost-effective warning systems. Moving fish cages to safer areas could be triggered by predictions of bloom movements from high-resolution oceanographic modeling in combination with particle tracking (Willis 2011).

We conclude that Ryggefjord is a dynamic fjord where both regional oceanographic conditions and the local setting drive the distribution and composition of the jellyfish community on short time scales, with species dominance shifting from ctenophores in early summer to hydrozoans in late summer/early autumn. Both taxa have been reported to cause problems for fisheries and/or aquaculture operations in northern Norway (Table 5), and their monitoring and management is therefore advisable near aquaculture facilities. Different taxa dominated in different locations within the fjord, where advection events and wind conditions likely contribute to the spatial structuring of the jellyfish distribution. Local populations of hydrozoans, including Obelia spp., probably complete their life cycle in the fjord and use submerged artificial structures as substrate. This is the first account of D. typicum in an Arctic coastal system, and its interactions with farmed fish are currently unknown. To improve prediction capabilities for these different blooms, both the spatial and seasonal dynamics of species successions, and the potential for oceanic advection to produce bloom-like aggregations of jellies, need to be studied in more detail. Better knowledge of the autecology of individual species, including depth ranges, thermal tolerances, reproductive optima and phenology, is required to understand bloom dynamics.

Acknowledgements. This study was supported by the Norwegian Research Council (VRIBEDRIFT program Finnmark, no. ES548990), Cermaq Norway and Akvaplan-niva AS. We thank the Cermaq staff in Ryggefjord and S. B. Småge for assistance with seagoing activities and help with the sampling. Sofus L. Olsen from the Norwegian Food Safety Authority (Mattilsynet) and Sverre B. Småge kindly provided information on fish behavior and health effects in the farmed fish in Ryggefjord.

\section{LITERATURE CITED}

Albretsen J, Sperrevik AK, Staalstrøm A, Sandvik AD, Vikebø F, Asplin L (2011) NorKyst-800 Report No. 1user manual and technical descriptions. Fisken og Havet 2/2011. Institute of Marine Research, Norway

* Altschul SF, Madden TL, Schäffer AA, Zhang J, Zhang Z, Miller W, Lipman DJ (1997) Gapped BLAST and PSIBLAST: a new generation of protein database search programs. Nucleic Acids Res 25:3389-3402

Anderson MJ, Robinson J (2003) Generalized discriminant analysis based on distances. Aust NZ J Stat 45:301-318

Anderson MJ, Willis TJ (2003) Canonical analysis of principal coordinates: a useful method of constrained ordination for ecology. Ecology 84:511-525

* Båmstedt U, Fosså JH, Martinussen MB (1998) Mass occurrence of the physonect siphonophore Apolemia uvaria (Lesueur) in Norwegian waters. Sarsia 83:79-85

Baxter EJ, Sturt MM, Ruane NM, Doyle TK, McAllen R, Harman L, Rodger HD (2011) Gill damage to Atlantic salmon (Salmo salar) caused by the common jellyfish (Aurelia aurita) under experimental challenge. PLOS ONE 6:4: e18529

Beldring S, Engeland K, Roald LA, Sælthun NR, Voksø A (2003) Estimation of parameters in a distributed precipitation-runoff model for Norway. Hydrol Earth Syst Sci 7: 304-316

Blackett M, Lucas CH, Harmer RA, Licandro P (2015) Population ecology of Muggiaea atlantica (Cnidaria, Siphonophora) in the Western English Channel. Mar Ecol Prog Ser 535:129-144

Boeck A (1866) Om to tilsyneladende bilateral-symmetriske Hydromeduser: Dipleurosoma typica og Stuvitzii. Videnskabelige Meddelelser fra den naturhistoriske Forening i Köbenhavn, p 131-140 (in Danish)

* Boero F, Bouillon J, Gravili C, Miglietta MP, Parsons T, Piraino S (2008) Gelatinous plankton: irregularities rule the world (sometimes). Mar Ecol Prog Ser 356:299-310

*Botz L, Cheung WW, Kleisner K, Pakhomov E, Pauly D (2012) Increasing jellyfish populations: trends in large marine ecosystems. Hydrobiologia 690:3-20

Bruno DW, Ellis AE (1985) Mortalities in farmed Atlantic salmon associated with the jellyfish Phialella quadrata. Bull Eur Assoc Fish Pathol 5:64-65

* Chen C, Liu H, Beardsley RC (2003) An unstructured, finitevolume, three-dimensional, primitive equation ocean model: application to coastal ocean and estuaries. J Atmos Ocean Technol 20:159-186

Condon RH, Duarte CM, Pitt KA, Robinson KL and others (2013) Recurrent jellyfish blooms are a consequence of global oscillations. Proc Natl Acad Sci USA 110: 1000-1005

Cornelius PFS (1995) North-west European thecate hydroids and their medusae. Part 1. Introduction, Laodiceidae to Haleciidae. Synopses of the British Fauna New Series 50:1-347

* Delannoy CMJ, Houghton JDR, Fleming NEC, Ferguson HW (2011) Mauve stingers (Pelagia noctiluca) as carriers of the bacterial fish pathogen Tenacibaculum maritimum. Aquaculture 311:255-257

DKNVS/NTVA (2012) Verdiskaping basert på produktive hav i 2050. Det Kongelige Norske Videnskabers Selskap og Norges Tekniske Vitenskapsakademi, Oslo (in Norwegian)

* Doyle TK, De Haas H, Cotton D, Dorschel B and others 
(2008) Widespread occurrence of the jellyfish Pelagia noctiluca in Irish coastal and shelf waters. J Plankton Res 30:963-968

Duarte CM, Pitt KA, Lucas CH, Purcell JE and others (2013) Is global ocean sprawl a cause of jellyfish blooms? Front Ecol Environ 11:91-97

Emelianov D (2011) Maneter kveler oppdrettsfisk i Troms. Nordlys. www.nordlys.no/nyheter/maneter-kveleroppdrettsfisk-i-troms/s/1-79-5753434 (accessed 30 January 2017) (in Norwegian)

Eriksen E, Prozorkevich D, Trofimov A, Howell D (2012) Biomass of scyphozoan jellyfish, and its spatial association with 0-group fish in the Barents Sea. PLOS ONE 7: e33050

Falkenhaug T (1996) Distributional and seasonal patterns of ctenophores in Malangen, northern Norway. Mar Ecol Prog Ser 140:59-70

Fosså JH (1998) Invasjon av kolonimaneten Apolemia langs norskekysten i 1997. Fisken og Havet, særnummer 2:63-70 (in Norwegian)

Fosså JH, Asplin L (2002) Kolonimaneten Apolemia uvaria dreper laks langs kysten. Havets Miljø, p 30-34 (in Norwegian)

Fosså JH, Flood PR, Olsen AB, Jensen, F (2003) Små og usynlige, men plagsomme maneter av arten Muggiaea atlantica. Havets Miljø, p 99-103 (in Norwegian)

Haddock SH, Case JF (1995) Not all ctenophores are bioluminescent: Pleurobrachia. Biol Bull 189:356-362

Hall TA (1999) BioEdit software, version 5.0.9. North Carolina State University, Raleigh, NC

Hellberg H, Olsen AB, Jensen F (2003) Clinical signs and histopathology in farmed Atlantic salmon (Salmo salar) associated with large numbers of the jellyfish Muggiaea atlantica, (Siphonophore). Book of Abstracts, 11th EAFP International Conference, September 2003, Malta, p 52

Hosteland LTS (2016) Måtte slakte ut Ecomerden. Kyst.no. http://kyst.no/nyheter/matte-slakte-ut-ecomerden/ (accessed 30 January 2017) (in Norwegian)

Kramp PL (1959) The Hydromedusae of the Atlantic Ocean and adjacent waters. Dana-Report 46:1-283

Kvile K (2015) Rødt slim plager fiskere. Fiskeribladet. https: //fiskeribladet.no/nyheter/?artikkel=43734 (accessed 2 July 2017) (in Norwegian)

Lo WT, Purcell JE, Hung JJ, Su HM, Hsu PK (2008) Enhancement of jellyfish (Aurelia aurita) populations by extensive aquaculture rafts in a coastal lagoon in Taiwan. ICES J Mar Sci 65:453-461

Lucas CH, Gelcich S, Uye SI (2014) Living with jellyfish: management and adaptation strategies. In: Pitt KA, Lucas $\mathrm{CH}$ (eds) Jellyfish blooms. Springer, Dordrecht, p 129-150

Majaneva S (2014) Understanding the biodiversity and ecological importance of ctenophores-lessons from Arctic and Baltic Mertensia ovum. W \& A de Nottbeck Foundation Sci Rep 41:1-74

Majaneva S, Majaneva M (2013) Cydippid ctenophores in the coastal waters of Svalbard: is it only Mertensia ovum? Polar Biol 36:1681-1686

Makabe R, Furukawa R, Takao M, Uye SI (2014) Marine artificial structures as amplifiers of Aurelia aurita s.l. blooms: a case study of a newly installed floating pier. J Oceanogr 70:447-455

Editorial responsibility: John Costello (Guest Editor), Providence, Rhode Island, USA
Marcos-López M, Mitchell SO, Rodger HD (2016) Pathology and mortality associated with the mauve stinger jellyfish Pelagia noctiluca in farmed Atlantic salmon Salmo salar L. J Fish Dis 39:111-115

McGinnity P, Prodöhl P, Ferguson A, Hynes R and others (2003) Fitness reduction and potential extinction of wild populations of Atlantic salmon, Salmo salar, as a result of interactions with escaped farm salmon. Proc R Soc Lond B Biol Sci 270:2443-2450

* McManus GB, Katz LA (2009) Molecular and morphological methods for identifying plankton: What makes a successful marriage? J Plankton Res 31:1119-1129

Merceron M, Le Fevre-Lehoerff G, Bizouarn Y, Kempf M (1995) Fish and jellyfish in Brittany (France). Equinoxe $56: 6-8$

Mianzan H, Quiñones J, Palma S, Schiariti A, Acha EM, Robinson K, Graham W (2014) Chrysaora plocamia: a poorly understood jellyfish from South American Waters. In: Pitt KA, Lucas CH (eds) Jellyfish blooms. Springer, Dordrecht, p 219-236

Mills CE, Haddock SHD (2007) Ctenophores. In: Carlton JT (ed) Light and Smith's manual: intertidal invertebrates of the Central California Coast, 4th edn. University of California Press, Berkeley, CA, p 189-199

Nilsen PM (2011) Manetinvasjon i oppdrettsanlegg - tettet gjellene til fiskene. TV2.no. www.tv2.no/a/3597991 (accessed 31 January 2017) (in Norwegian)

Oppegård GG (2008) Ny manet invaderer kysten. In: På Høyden. Uavhengig avis for Universitetet i Bergen. http://pahoyden.no/2008/09/ny-manet-invaderer-kysten (accessed 30 January 2017) (in Norwegian)

Purcell JE (2012) Jellyfish and ctenophore blooms coincide with human proliferations and environmental perturbations. Annu Rev Mar Sci 4:209-235

*Purcell JE, Uye SI, Lo WT (2007) Anthropogenic causes of jellyfish blooms and direct consequences for humans: a review. Mar Ecol Prog Ser 350:153-174

Richardson AJ, Bakun A, Hays GC, Gibbons MJ (2009) The jellyfish joyride: causes, consequences and management responses to a more gelatinous future. Trends Ecol Evol $24: 312-322$

Rodger HD, Henry L, Mitchell SO (2011) Non-infectious gill disorders of marine salmonid fish. Rev Fish Biol Fish 21: 423-440

Russell FRS (1953) The medusae of the British Isles. Cambridge University Press, Cambridge

* Schuchert P (2005) Species boundaries in the hydrozoan genus Coryne. Mol Phylogenet Evol 36:194-199

* Solomos S, Kallos G, Kushta J, Astitha M, Tremback C, Nenes A, Levin Z (2011) An integrated modeling study on the effects of mineral dust and sea salt particles on clouds and precipitation. Atmos Chem Phys 11:873-892

Tiller RG, Mork J, Liu Y, Borgersen AL, Richards R (2015) To adapt or not adapt: assessing the adaptive capacity of artisanal fishers in the Trondheimsfjord (Norway) to jellyfish (Periphylla periphylla) bloom and purse seiners. Mar Coast Fish 7:260-273

Varela AP (2015) Vertical distributions of zooplankton using the Video Plankton Recorder in two high-latitude fjords. MSc thesis, University of Tromsø

Willis J (2011) Modelling swimming aquatic animals in hydrodynamic models. Ecol Modell 222:3869-3887

Submitted: February 1, 2017; Accepted: July 24, 2017

Proofs received from author(s): October 3, 2017 